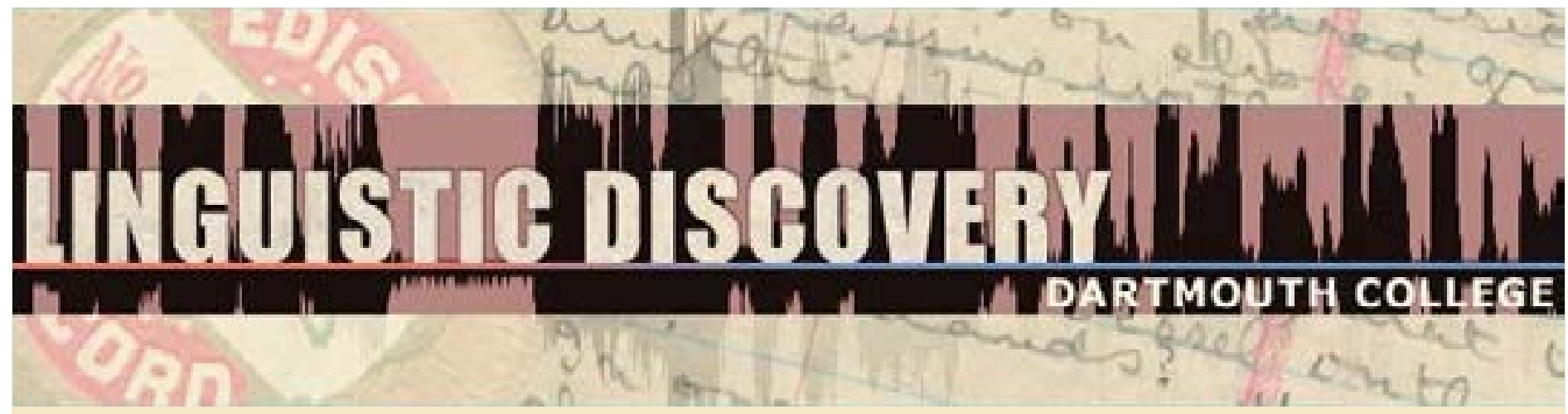

\begin{tabular}{|l|}
\hline Volume 8 \\
Issue 1 \\
2010 \\
\hline
\end{tabular}

\title{
How Conceptual Are Semantic Maps?
}

Andrea Sansò

Università dell'Insubria - Como

doi: 10.1349/PS1.1537-0852.A.354

url: http://journals.dartmouth.edu/cgi-bin/WebObjects/ Journals.woa/1/xmlpage/1/article/354 Copyright to this article is held by the authors. ISSN 1537-0852 linguistic-discovery.dartmouth.edu 


\title{
How Conceptual Are Semantic Maps?
}

\author{
Andrea Sansò
}

\author{
Università dell'Insubria - Como
}

The question addressed in this paper is whether (and to what extent) a semantic map aimed at representing the multifunctionality of a given construction (or set of constructions) in discourse can be thought of as endowed with conceptual reality. To be considered as a mental representation that is essentially similar in all human brains, such a map should meet two requirements: (i) its nodes should be bundles of semantic and pragmatic properties that form conceptual archetypes, that is, ways of conceptualizing and categorizing dynamic or static configurations that are fundamental to human experience; (ii) there should be a high degree of regularity in the data material, i.e. each construction should be associated with a node or a contiguous set of nodes in a regular way. However, observing the use of grammatical constructions in discourse provides us with compelling evidence that discourse contexts are complex entities involving many different variables, and that "a perfect fit is not the usual state of affairs for models of complex human behavior (including language)" (Croft and Poole 2008:6). Based on a previous analysis of various passive and impersonal constructions in a parallel corpus of five European languages, I will argue that a first-generation semantic map representing the distribution of these constructions in discourse and comprising a few conceptual archetypes may be only an idealized abstraction over the conflicting evidence of the association between discourse contexts and construction types. As an idealization, such a map is not particularly informative as to language-specific tendencies and idiosyncrasies and does not allow us to analyze all the datasets that we might be interested in analyzing. On the other hand, a second-generation semantic map proves to be a more reliable tool for representing variation in discourse and does not force the analyst to posit (and multiply) conceptual structures where there may be none.

\section{Semantic Maps and Conceptual Reality ${ }^{1}$}

Some practitioners of the semantic-map method are rather reluctant to consider semantic maps as "mental" or "cognitive" maps, i.e. as "direct representation[s] of the relationships between meanings in speakers' minds" (Haspelmath 2003:233, my emphasis). According to others (e.g. Croft 2001), semantic maps make conceptual sense and provide objective evidence as to which meanings are cognitively closely related. In Croft's words, they accurately reflect "the geography of the human mind, which can be read in the facts of the world's languages in a way that the most advanced brain scanning techniques cannot even offer us" (Croft 2001:364).

Representatives of the former approach usually maintain a neutral stance as to whether nodes on semantic maps represent different uses (= contextual meanings) or different senses (= conventional meanings) of grams (e.g. Haspelmath 2003:212-213). The essential idea in the latter approach is that "the use of a single grammatical form ... for a set of functions implies that speakers conceptualize those functions as similar or related to one another" (Croft and Poole 2008:5). Those who credit conceptual reality to semantic maps generally assume that nodes on semantic maps are conceptual structures or conceptual archetypes (Kemmer 2003:98); that is,

${ }^{1}$ I wish to thank Martin Haspelmath and an anonymous referee for their insightful comments on a first draft of this paper.

Linguistic Discovery 8.1:288-309 
they represent ways of conceptualizing and categorizing dynamic or static configurations that are fundamental to human experience (Croft 2001:98; Kemmer 1993, 2003:97ff.). The arrangement of nodes on a map mirrors the arrangement of the corresponding conceptual structures (or functions) in the speaker's mind (Croft 2001:93). Kemmer's statements in (1)-(2) should serve as an illustration of this position:

(1) Situation types [i.e. nodes on the semantic map of event elaboration, $A S$ ] can be thought of as sets of situational or semantic/pragmatic contexts that are systematically associated with a particular form of expression. By 'semantic/pragmatic contexts' I do not mean simple 'real world contexts' existing independently of the language-user; situational contexts include 'real world' information, but that information is necessarily filtered through the conceptual apparatus of the speaker. This conception of situational contexts thus allows for the obvious role of the language-user in construing particular real world situations in different ways (Kemmer 1993:7, my emphasis)

(2) Marking systems in the reflexive/middle domain integrally involve alternative conceptualizations of participant structure and event structure as a whole. Languages may differ as to the morphosyntactic means they have conventionalized for coding such differences in conceptualization, but the variation is highly constrained by the underlying conceptual system (Kemmer 2003:115).

Conceptual structures are not intended as merely semantic in the truth-conditional sense of this term. Rather, they are meant to represent all of the conventionalized knowledge associated with a given gram, which may also include the discourse conditions under which the gram is used (Croft 2001:19).

This position rests on the (more or less implicit) assumption that there is no separate pragmatic component, and that any linguistic property traditionally analyzed in terms of pragmatics is semantically or conceptually determined in the first place. As Croft (2001:93) puts it, "[C]onceptual space also represents conventional pragmatic or discourse-functional or information-structural or even stylistic and social dimensions of the use of a grammatical form or construction." As a consequence, semantic maps lend themselves well to being applied to phenomena that are sensitive to discourse conditions such as the relative prominence and the information status of arguments and situations (e.g. voice constructions, Croft 2001:283ff.; the coordination/subordination continuum, Croft 2001:320ff.).

The question addressed in this paper is whether (and to what extent) a semantic map aimed at representing the multifunctionality of a given construction (or set of constructions) in discourse can be thought of as endowed with conceptual reality. To be considered as a mental representation that is essentially similar in all human brains such a map should meet two requirements:

(i) conceptual relevance: its nodes should be clearly identifiable bundles of semantic and pragmatic properties that form conceptual archetypes in the sense of Kemmer (2003:98); 
(ii) high degree of regularity in the data material: these bundles of features should represent the typical contexts of use of a given (set of) construction(s), and each construction should be associated with a node or a contiguous set of nodes in a regular way.

However, observing the use of grammatical constructions in discourse - their "natural habitat" (Givón 1995:309) - provides us with compelling evidence that discourse contexts are complex entities involving many different variables and that "a perfect fit is not the usual state of affairs for models of complex human behavior (including language)" (Croft and Poole 2008:6). A certain amount of "noise" remains: what we usually find are preferences and tendencies, not categorical form-function mappings. Occasionally, forms are mapped onto functions that are generally paired with other forms in a given language. The noise is particularly rampant when searching for functional equivalents across languages (for instance looking at translation equivalents in parallel texts).

Based on a previous analysis of various passive and impersonal constructions in a parallel corpus of five European languages (Sansò 2006; see Section 3), I will argue that a firstgeneration $^{2}$ semantic map representing the distribution of these constructions in discourse and comprising a few cognitively-significant situation types (in the sense of Kemmer 1993:7, see (1) above) may be only an idealized abstraction over the conflicting evidence of the association between discourse contexts and construction types. As an idealization, such a map is not particularly informative about language-specific tendencies and idiosyncrasies and does not allow us to analyze all the datasets that we might be interested in analyzing. On the other hand, a second-generation semantic map (created following the method described by Levinson et al. 2003; Cysouw 2007; Wälchli 2006/7; Croft and Poole 2008, among others; see Section 2) proves to be a more reliable tool for representing variation in discourse and does not force the analyst to posit (and multiply) conceptual structures where there may be none. Moreover, the comparison between a first and a second-generation semantic map highlights the fact that the two approaches aim to represent two rather distinct facts. First-generation semantic maps may be thought of as hypotheses concerning the cognitive relevance of different conceptualizations of states of affairs as reconstructed from the facts of human language. They are grounded in linguistic facts but also characterized by conceptual purity and uncontaminated by the vagaries of usage. Second-generation semantic maps are representations of linguistic variation in the strict sense, as they allow the linguist to obtain general tendencies without losing linguistic detail, and to do typology in the absence of types, so to speak. Though divided by two different

\footnotetext{
${ }^{2}$ The terms first-generation and second-generation semantic maps will be used throughout this paper as convenient labels referring to maps constructed with two different methods. First-generation semantic maps (also classical maps, van der Auwera 2008) are constructed following the technique described by Haspelmath (2003: 215ff.). Second-generation semantic maps are higher resolution maps based on distance matrices. The latter often make use of Multidimensional Scaling (MDS) in order to visualize multidimensional data on a bidimensional surface (Levinson et al. 2003; Wälchli 2006/7: 7ff.; Cysouw 2007; Croft and Poole 2008). This distinction is useful for expository purposes, but the reader should be warned of an unwanted oversimplification that it may trigger: the distinction in question does not imply that creators of second-generation semantic maps do not attach any conceptual significance to their maps. Croft and Poole (2008: 31), for instance, argue that even the spatial model resulting from MDS analysis is a representation of "the conceptual organization of the mind"; Levinson et al. (2003: 511) do not explicitly deny conceptual status to the clusters of spatial topological relations (e.g. the ON/OVER cluster) that can be identified on their map and discuss two possible conceptions of the "intension" corresponding to these clusters. In the case of the ON/OVER cluster, for instance, this "intension" may be thought of as an underspecified meaning ([+ SUPERPOSITION, \pm CONTACT $]$ ) or as a composite category with two foci ([+ SUPERPOSITION + CONTACT] and [+SUPERPOSITION CONTACT]).
} 
epistemological stances, the two approaches may usefully complement each other provided that the differences in scope between the two are not downplayed.

This paper is organized as follows: in Section 2 I will briefly discuss the methodology of second-generation semantic maps; in Section 3, after a general discussion of voice as a functional domain concerned with the human cognition and representation of actions/events, I will introduce the corpus data used for the present study and discuss the distribution of passive and impersonal constructions in European languages (3.1) - a classical semantic map of agent defocusing based on this data will also be presented; in Section 3.2 the representational power of this first-generation map is weighed against a second-generation semantic map based on the same data, and in Section 4 some general conclusions will be presented.

\section{Beyond Conceptual Reality: Second-Generation Semantic Maps}

In the "trade-off between accuracy and coverage" (Wälchli 2006/7:5; see also Cysouw 2007), first-generation semantic maps aim at maximizing coverage at the expenses of accuracyconceptually sound generalizations are indeed possible only if a significantly large number of languages is taken into consideration. Somewhat paradoxically, this leads to unavoidable difficulties in terms of conceptual plausibility: if two functions are put on the map if there is at least one pair of languages that employ different grams to encode these functions, frequent and non-frequent multifunctionality patterns of grams end up being treated similarly. This results in geometrical "distortions" in the representation of relations between nodes. ${ }^{3}$ Moreover, the implicational value attached to classical maps makes them rather uninteresting when no clear implicational patterns emerge in the data as in the case of the so-called "vacuous maps" (i.e. maps "in which all the functions have connecting lines with all other functions," Haspelmath 2003:218). Cross-linguistic variation, however, is still present even in the absence of implicational patterns and deserves to be represented and explored in its own right.

The lack of consideration for frequency patterns has led some authors to propose a new method of constructing semantic maps which revolves around the idea that semantic maps should retain as much linguistic detail as possible. This method (described, among others, by Levinson et al. 2003; Cysouw 2007:236ff.; Wälchli 2006/7:11ff.; Croft and Poole 2008) allows us to create higher-resolution maps in which there are no nodes and lines as in the classical model. In second-generation semantic maps, similarity between uses/functions is simply represented by proximity, and difference by distance. When these maps are applied to multifunctional grams in discourse, they do not contain idealizations/abstractions from several contexts of use, and what is represented on the map is the whole array of functions/contexts of use of a given form or set of forms. As "implicational relationships tend to emerge more easily where there is low resolution," (Wälchli 2006/7:38) second-generation semantic maps are not implicational.

The idea behind this method is fairly simple: semantic/conceptual space is not directly measurable, whereas cross-linguistic variation is. Accordingly, the focus of interest of the creator of the map should switch from the idealized, low-resolution representation of the underlying conceptual structures to a full-scale representation of linguistic variation:

\footnotetext{
${ }^{3}$ This does not amount to saying that classical semantic maps are untrustworthy representations of grammatical variation. These distortions are in practice often amended by looking for language-specific explanations for rare multifunctionality patterns in the "usual va et vient between arm chair hypothesis building and empirical validation" (van der Auwera 2008: 44).
} 
(3) semantic space cannot be measured directly, which is why categorization across different languages is resorted to in order to "reconstruct" it. However, to be honest we do not know whether there is such a thing as a continuous semantic space that would be analogous to phonetic space; so it must be a matter of discussion whether what is "reconstructed" in semantic maps is real in any form. In any case it is something of a hybrid nature: the outcome of a comparison of a large number of different emic categorization patterns as represented in etic data (Wälchli 2006/7:36, my emphasis)

The ability to retain details makes second-generation semantic maps particularly flexible tools when using parallel texts as a source of cross-linguistic data (Wälchli 2006/7:7ff.). Higher resolution helps the analyst to identify both general tendencies in form/meaning pairings and less regular associations (Wälchli 2006/7:43-44). In a parallel corpus, unusual form/meaning pairings may correspond to unusual construal choices made by the translator or may be triggered by the inherently hybrid nature of a given context, which makes it likely to be associated with different gram types across languages. Unusual form/meaning pairings will appear on the map as outliers (i.e. points falling outside the high-density areas corresponding to more regular form-meaning associations) and may cast light on language-specific idiosyncrasies that could not be discovered otherwise.

The use of passive and impersonal constructions is almost never obligatory, and cannot be predicted in any automatic way from a given set of discourse conditions. But even though they are not obligatory, such constructions are generally motivated, that is, it is possible to identify the factors favoring their use. These factors have primarily to do with conceptually-relevant distinctions (i.e. with different conceptualizations of the event and its participants), but the constructions in question are also used for pragmatic purposes (i.e. they fulfill communicative goals pertaining to the discourse relevance of event participants). In other words, passive and impersonal constructions straddle the semantics-pragmatics boundary and are therefore particularly promising if we want to address the question of whether conceptual reality is a feasible requirement for a semantic map aimed at representing the multifunctionality of grams in discourse. It is to this question that I now turn.

\section{Passive and Impersonal Constructions in some European Languages}

In a previous study (Sansò 2006), I examined the distribution of passive and impersonal constructions in a parallel corpus of 5 European languages. The corpus consisted of an Italian text along with its Danish, Modern Greek, Polish, and Spanish translations. The text selected for this purpose was Umberto Eco's novel Il nome della rosa. Approximately 1100 passive and impersonal clauses were collected from the original version of the novel and compared with their translation equivalents. In the present study, two languages (French and Hungarian) have been added to the sample.

Although there is a low degree of genealogical diversity in the languages of the sample, there is a great deal of structural variation among the construction types used in these languages, which cover the main patterns of grammaticization of passive morphology identified by Haspelmath (1990). The constructions analyzed include (i) so-called periphrastic passives (Italian, Spanish, Danish, Polish, etc.); (ii) a morphologically marked middle diathesis (Modern Greek); (iii) passive and impersonal constructions in which a reflexive marker is used (Italian, 
Spanish, etc., henceforth reflexive passive/impersonal); (iv) so-called impersonal passives, that is constructions in which the predicate is associated with passive morphology, but there is either no patient, or the patient is marked in the same way in which it is marked in the active sentence (Polish, Danish). Moreover, (v) impersonal active clauses such as the so-called man-clauses (Danish), and (vi) constructions involving the impersonal or vague use of a personal pronoun or the corresponding inflected form of the verb (Modern Greek, Hungarian, etc.) are also represented in the sample. Hungarian has been added because in this language, besides a "vague they" construction, "passiveness does not have a systematic formal expression, that is, there are no passive constructions in which the verbal predicate manifests a specific passive form" (Dezső 1988:291).

\subsection{A first-generation semantic map of agent defocusing}

The functional domain of voice is said to have its "conceptual bases rooted in the human cognition of actions" (Shibatani 2006:219; see also Langacker 2006). Voice constructions are "means for expressing conceptual contrasts pertaining to the evolutionary properties of an action that the speaker finds relevant for communicative purposes" (Shibatani 2006:219). The passive and impersonal constructions discussed in this paper are associated with a general function which is commonly labeled agent defocusing (Shibatani 1985:832; Myhill 1997:840ff.; Sansò 2006:238ff.). This function is eminently discourse-sensitive, as the conditions under which the speaker/writer might want to downplay the agent are quite various. Accordingly, we ought to distinguish between different types of agent defocusing in order to do justice to the variety of specific circumstances associated with the use of passive and impersonal constructions across languages.

The data discussed in Sansò (2006) allow us to sufficiently identify two situation types involving two different types of agent defocusing. These situation types have been labeled patient-oriented process (Sansò 2006:238) and agentless generic event (Sansò 2006:242). A prototypical patient-oriented process represents a two-participant event from the point of view of the patient. In discourse this kind of conceptualization is employed to ensure coherence when the text is about a certain entity and this entity is the patient. In a patient-oriented process the agent is typically identifiable from the context, or even syntactically encoded as an oblique, but less discourse-central and individuated than the patient. In the Italian passage in (4) we can deduce from the context that Benno has been named assistant by the former librarian, but since the passage is about Benno, the use of the periphrastic passive enables the writer to create a topic chain (Givón 1983) and to link sentences to one another. The result is a coherent text that is easier to comprehend than an incoherent text with active clauses only: 
(4) "Ora che Malachia e Berengario sono morti, chi è rimasto a possedere i segreti della biblioteca?" "L'Abate, e l'Abate dovrà ora trasmetterli a Bencio... se vorrà..." "Perché se vorrà?" "Perché Bencio è giovane, è stato nominato aiuto quando Malachia era ancora vivo, è diverso essere aiuto bibliotecario e bibliotecario. Per tradizione il bibliotecario diventa poi abate..." (NRI: 423).

\begin{tabular}{|c|c|c|c|c|c|c|c|}
\hline $\begin{array}{l}\text { Perché } \\
\text { because }\end{array}$ & $\begin{array}{l}\text { Bencio } \\
\text { B. }\end{array}$ & $\begin{array}{l}\grave{e} \\
\text { be:PRS.3SG }\end{array}$ & $\begin{array}{l}\text { giovane } \\
\text { young }\end{array}$ & $\begin{array}{l}\text { è } \\
\text { be:PRS.3SG }\end{array}$ & $\begin{array}{l}\text { stato } \\
\text { be:РPTCP }\end{array}$ & $\begin{array}{l}\text { nominato } \\
\text { name:РРТСР }\end{array}$ & $\begin{array}{l}\text { aiuto } \\
\text { assistant }\end{array}$ \\
\hline $\begin{array}{l}\text { quando } \\
\text { when }\end{array}$ & $\begin{array}{l}\text { Malach } \\
\text { M. }\end{array}$ & $\begin{array}{l}\text { era } \\
\text { be:IPFV }\end{array}$ & $\begin{array}{l}\text { anc } \\
\text { still }\end{array}$ & $\begin{array}{l}\text { vivo } \\
\text { alive }\end{array}$ & & & \\
\hline
\end{tabular}

"Now that Malachi and Berengar are dead, who is left who possesses the secrets of the library?" "The abbot, and the abbot must now hand them on to Benno.... if he chooses...." "Why do you say 'if he chooses'?" "Because Benno is young, and he was named assistant while Malachi was still alive; being assistant librarian is different from being librarian. By tradition, the librarian later becomes abbot...." (NRE: 421).

Under the rubric of agentless generic event situations are included in which an agent, usually human, is understood to exist, but is defocused because of its genericity, as in the following Italian example:

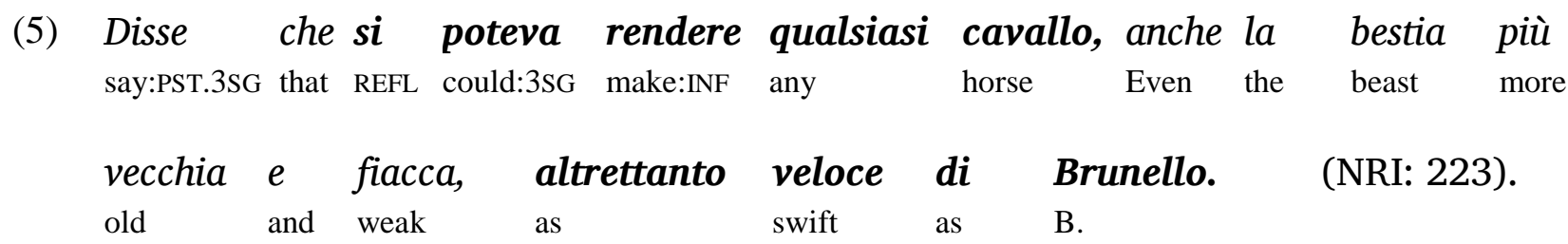

"He said that any horse, even the oldest and weakest animal, could be made as swift as Brunellus" (NRE: 219).

A more precise semantic characterization of these two situation types is given in Table 1, whereas Table 2 displays the preferential associations between these two situation types and construction types in the 5 languages of the original sample. In the appendix, some passages taken from the corpus exemplify these associations (they are removed from the body of the text for the sake of brevity; for a more extensive discussion of these passages, the reader is referred to Sansò 2006). 


\begin{tabular}{|c|c|c|}
\hline Variable & Agentless generic event & Patient-oriented process \\
\hline \multicolumn{3}{|l|}{ A(GENT): } \\
\hline genericity & $\begin{array}{l}\text { +generic: A represents virtually } \\
\text { all humanity or a subpart thereof } \\
\text { (e.g. people in a given location) }\end{array}$ & $\begin{array}{l}\text {-generic: } A \text { is a specific, identi- } \\
\text { fiable person }\end{array}$ \\
\hline number & plural & singular \\
\hline reason for defocusing $A$ & $\mathrm{~A}$ is generic & $\begin{array}{l}\text { A is less topical than P (or in- } \\
\text { ferable, unimportant) }\end{array}$ \\
\hline \multicolumn{3}{|l|}{ EVENT: } \\
\hline tense & present (atemporal) & past \\
\hline aspect & imperfective & perfective \\
\hline reality status & $\begin{array}{l}\text { irrealis (deontic, potential, habi- } \\
\text { tual, etc.) }\end{array}$ & realis \\
\hline \multicolumn{3}{|l|}{ P(ATIENT): } \\
\hline animacy & 土animate & +animate \\
\hline topicality & non-topical & topical \\
\hline genericity & typically generic & specific \\
\hline number & typically plural & singular \\
\hline
\end{tabular}

Table 1: Features of A, P, and the event in two types of agent defocusing (based on, and extending, Sansò 2006).

\begin{tabular}{|c|c|c|c|}
\hline Language & $\begin{array}{l}\text { Situation } \\
\text { type }\end{array}$ & Patient-oriented process & Agentless generic event \\
\hline Italian & & Periphrastic passive (ex. (4)) & $\begin{array}{l}\text { Reflexive passive / impersonal (ex. } \\
\text { (5)) }\end{array}$ \\
\hline Spanish & & $\begin{array}{l}\text { Periphrastic passive (ex. (10)) / } \\
\text { Reflexive passive/impersonal } \\
\text { (ex. (11)) }\end{array}$ & $\begin{array}{l}\text { Reflexive passive / impersonal (ex. } \\
\text { (12)) }\end{array}$ \\
\hline Polish & & Periphrastic passive (ex. (13)) & $\begin{array}{l}\text { Reflexive passive / impersonal (ex. } \\
\text { (14)) }\end{array}$ \\
\hline Danish & & Periphrastic passive (ex. (15)) & $\begin{array}{l}\text { man-construction (ex. (16)) / reflex- } \\
\text { ive passive/impersonal (ex. (17)) }\end{array}$ \\
\hline $\begin{array}{l}\text { Modern } \\
\text { Greek }\end{array}$ & & $\begin{array}{l}\text { Inflectional passive / middle } \\
\text { paradigm (ex. (18)) }\end{array}$ & $\begin{array}{l}\text { (Various) active constructions with } \\
\text { generic/vague subjects (2SG (ex. } \\
\text { (19)), 3PL (ex. (20)), 1PL) }\end{array}$ \\
\hline
\end{tabular}

Table 2: Situation types and construction types in five European languages (based on Sansò 2006).

The previous analysis has also underscored that there are contexts in the corpus that cut across the distinction between these two situation types. In particular, there are a handful of passages in the corpus in which the patient is not particularly topical. If we take referential distance and persistence (defined following Givón 1983:13-14) as indexes of topicality, patients in these clauses are not mentioned in the previous discourse span and rapidly decay after their mention. At the same time, however, the event takes place in the past - this implies the existence of one or 
more specific agents, which are sufficiently unimportant to be backgrounded even though the patient is not topical. In some languages of the sample, these contexts are encoded by the same constructions used to encode patient-oriented processes. In other languages the situation is more diverse, and various constructions appear to be associated with these contexts. Examples (21) to (23) in the appendix illustrate some of these cases. I have tentatively labeled these contexts bare happenings (Sansò 2006:240). This label is meant to describe a situation type in which the agent is (conceptualized as) sufficiently unimportant to be backgrounded even though the patient is not particularly topical. By way of exemplification, consider the passive and impersonal clauses in boldface in example (6) - their reference is quite vague, and there is no explicit mention of any of the people who might have mocked the faith of the simple or eviscerated the mysteries of God (although it is clear from the context that Abelard is indirectly responsible for this). Nor are the patients in these clauses particularly individuated. As a result, the events encoded by these clauses are not sharply delineated from (or highly distinguishable within) the setting in which they occur, and are presented in summary fashion. We might even venture a patientincorporating existential gloss for such clauses. For instance, we might gloss the first passive clause in (6) as there was faith-mocking. While somewhat forced, this gloss illustrates that the patient is not focused and that the event is conceptualized as a monadic unit:

"Venerabile Jorge, mi sembrate ingiusto quando trattate da castrato Abelardo, perché sapete che incorse in tale triste condizione per la nequizia altrui..." "Per i suoi peccati. Per l'albagia della sua fiducia nella ragione dell'uomo. Cosi la fede dei semplici venne irrisa, $i$ misteri di Dio furono sviscerati (o si tentò, stolti coloro che lo tentarono), questioni che riguardavano le cose altissime vennero trattate temerariamente, si irrise ai padri perché avevano ritenuto che tali questioni andavano piuttosto sopite che sciolte." "Non sono d'accordo, venerabile Jorge. Dio vuole da noi che esercitiamo la nostra ragione su molte cose oscure su cui la scrittura ci ha lasciato liberi di decidere” (NRI: 139).

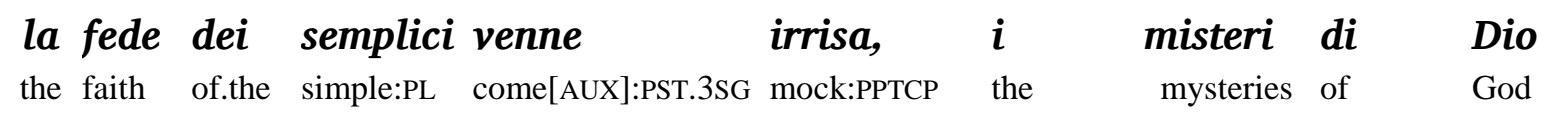

furono sviscerati ... questioni che riguardavano le cose altissime be:PST.3PL eviscerate:PPTCP questions REL regard:IPFV.3PL the things loftiest

vennero trattate temerariamente, si irrise ai padri come[AUX]:PST.3PL treat:PPTCP recklessly REFL mock:PST.3SG to.the fathers

"Venerable Jorge, you seem to me unjust when you call Abelard a castrate, because you know that he incurred that sad condition through the wickedness of others..." "For his sins. For the pride of his faith in man's reason. So the faith of the simple was mocked, the mysteries of God were eviscerated (or at least this was tried, fools they who tried), questions concerning the loftiest things were treated recklessly, the fathers were mocked because they had considered that such questions should have been subdued, rather than raised." "I do not agree, venerable Jorge. Of us God demands that we apply our reason to many obscure things about which Scripture has left us free to decide" (NRE: 132). 
The distinction between these contexts and patient-oriented processes is susceptible to linguistic coding - there are some constructions such as the impersonal passive of Danish $($ der + blive + past participle) and the so-called -no/-to construction in Polish that appear to correlate preferentially with such contexts. This is sufficient enough to put the distinction between patient oriented-processes and bare happenings on a first-generation semantic map of agent defocusing.

However, while the first two situation types emerge rather clearly from the analysis of the corpus, and their association with different construction types is fairly regular, the so-called bare happening is less clearly differentiated from both the patient-oriented process and the agentless generic event. This emerges rather clearly when looking at Table 3, in which the prototypical features of the three situation types are displayed synoptically. ${ }^{4}$ While the patient-oriented process and the agentless generic event are maximally opposed on several dimensions, the bare happening is somewhere mid-way between these two situation types.

\begin{tabular}{llll}
\hline & Patient-oriented process & Bare happening & Agentless generic event \\
\hline Individuation of P & + & - & - \\
Individuation of A & \pm & - & - \\
Reason for defo- & A is less topical than P (or & A is irrele- & A is generic \\
cusing A & irrelevant/unimportant) & vant/unimportant & \\
Reality status & Realis & Realis & $\begin{array}{l}\text { Irrealis (deontic, poten- } \\
\text { tial) }\end{array}$ \\
Aspect & Perfective & Perfective & Imperfective \\
\hline
\end{tabular}
Table 3: Prototypical features of the three situation types (based on Sansò 2006).

The three situation types identified above form a non-vacuous semantic map because there are no cases in the sample in which the same construction is used for patient-oriented processes and agentless generic events without encoding, at the same time, the situation type labeled bare happening. The non-vacuity of the map in Figure 1, however, may be falsified at any time given the low degree of genealogical diversity of the languagees in the sample.

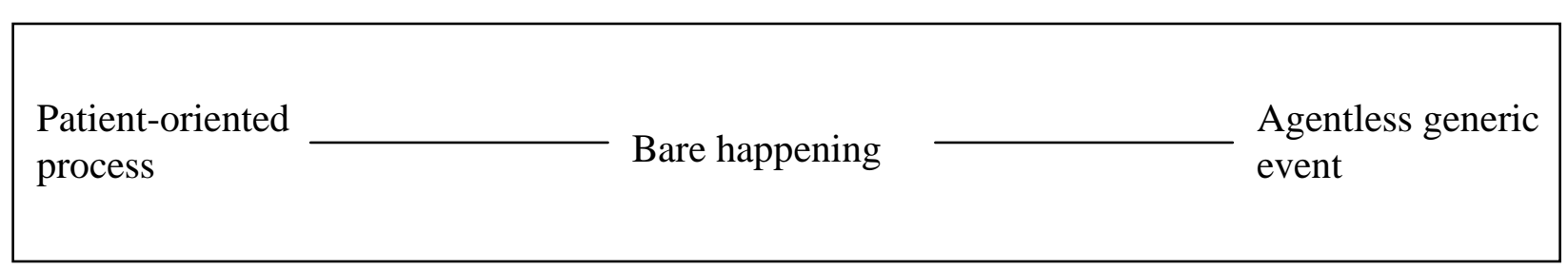

Figure 1: A first-generation semantic map of agent defocusing.

The association between the three situation types and construction types is displayed in Table 4.

\footnotetext{
${ }^{4}$ It must be emphasized that the three situation types in question are to be conceived of as prototypes. This means that they are clusters of semantic properties that tend to co-occur in the most typical uses of the constructions under scrutiny but at the same time need not be present in all these uses. In other words, despite the notation used (which makes use of plus and minus signs), these traits are not intended in terms of feature semantics, i.e. as necessary and sufficient features.
} 


\begin{tabular}{|c|c|c|c|}
\hline $\begin{array}{c}\text { Situation type } \\
\text { Language } \downarrow\end{array} \stackrel{\rightarrow}{\rightarrow}$ & $\begin{array}{l}\text { Patient-oriented } \\
\text { process }\end{array}$ & appening & Agentless generic event \\
\hline Italian & \multirow[t]{2}{*}{ Periphrastic passive } & \multicolumn{2}{|c|}{ Reflexive passive/impersonal } \\
\hline Spanish & & \multicolumn{2}{|c|}{ Reflexive passive/impersonal } \\
\hline Polish & Periphrastic passive & $\begin{array}{l}\text { Impersonal passive } \\
(- \text { no/-to })\end{array}$ & $\begin{array}{c}\text { Reflexive passive / } \\
\text { impersonal }\end{array}$ \\
\hline Danish & Periphrastic passive & $\begin{array}{l}\text { Impersonal passive } \\
(\text { der }+ \text { blive }+ \text { verb })\end{array}$ & $\begin{array}{c}\text { Reflexive passive / imper- } \\
\text { sonal / } \\
\text { man-construction }\end{array}$ \\
\hline Modern Greek & \multicolumn{2}{|c|}{ Inflectional passive / middle paradigm } & $\begin{array}{l}\text { (Various) active construc- } \\
\text { tions with generic/vague } \\
\text { subjects (2SG, 3PL, 1PL) }\end{array}$ \\
\hline
\end{tabular}

Table 4: Situation types and construction types in five European languages (expanded).

Even in the case of more firmly established form-function correlations, there is a certain amount of free choice in the parallel corpus examined. For instance, in a number of contexts in which the patient is topical, we find a reflexive passive in the Spanish version of the novel (a construction type that correlates preferentially with agentless generic events in the other languages of the sample). Moreover, there is no principled way to describe under which discourse conditions the various active constructions with a vague subject in Modern Greek are used. Similarly, the manconstruction and the reflexive passive (the so-called $-s$ form) in Danish appear to alternate rather freely in the same (or in very similar) contexts.

\subsection{A second-generation map of agent defocusing}

The map in Figure 2 has been constructed following a procedure similar to that described by Wälchli (2006/7:11ff.). It is based on a database of 180 contextually embedded passages from the corpus (the objects represented on the map). For each passage, the passive/impersonal construction type used in each language has been reported on a table. If a language does not use a passive or impersonal construction in that passage, the cell has been left empty. ${ }^{5}$ For any pair

\footnotetext{
${ }^{5}$ Cells are left empty also whenever the relevant passage is omitted (or condensed) in the translation. These cases were more frequent than expected. An anonymous referee objects that leaving cells empty is a strong data reduction and constitutes a drawback of this second-generation map. This choice, however, has been determined by the difficulty of categorizing "lack of passive" as a homogeneous strategy with some linguistic significance. Whereas active sentences with generic subjects (you, they, "man/on") are explicitly included in the tables, in most cases lack of passive simply means that the agent, which in the original text appears as oblique, becomes the subject of the translated clause, as in (i-b). In other cases, the agent is not overt in the original text and is reconstructed by the translator on the basis of general (or text-specific) knowledge, as in (ii-b):
}

(i) a. era stato visto dagli altri monaci in coro durante compieta ma non era ricomparso a mattutino (NRI: 40).

b. los otros monjes lo habían visto en el coro durante completas, pero no había asistido a maitines (NRS: $50)$.

'he had been seen by other monks in choir during compline but had not reappeared at matins' (NRE: 31).

(ii) a. Ne lodò la saggezza, ne palesò la fama, e avvertì che era stato pregato di investigare sulla morte di Adelmo (NRI: 104). 
of passages, the number of similarities in languages is divided by the total number of languages in which both values are attested (i.e., empty cells are not included in the calculus). The result is a similarity matrix of $180 \times 180$ cells. A simple application (PerMap) takes this matrix as its input and translates it into a bidimensional representation of distance between objects $(=$ the 180 contextually embedded passages, represented as small circles).

\section{Passive and impersonal constructions in Umberto Eco's novel II Nome della Rosa \\ Objective Function Value $=0.168191$}

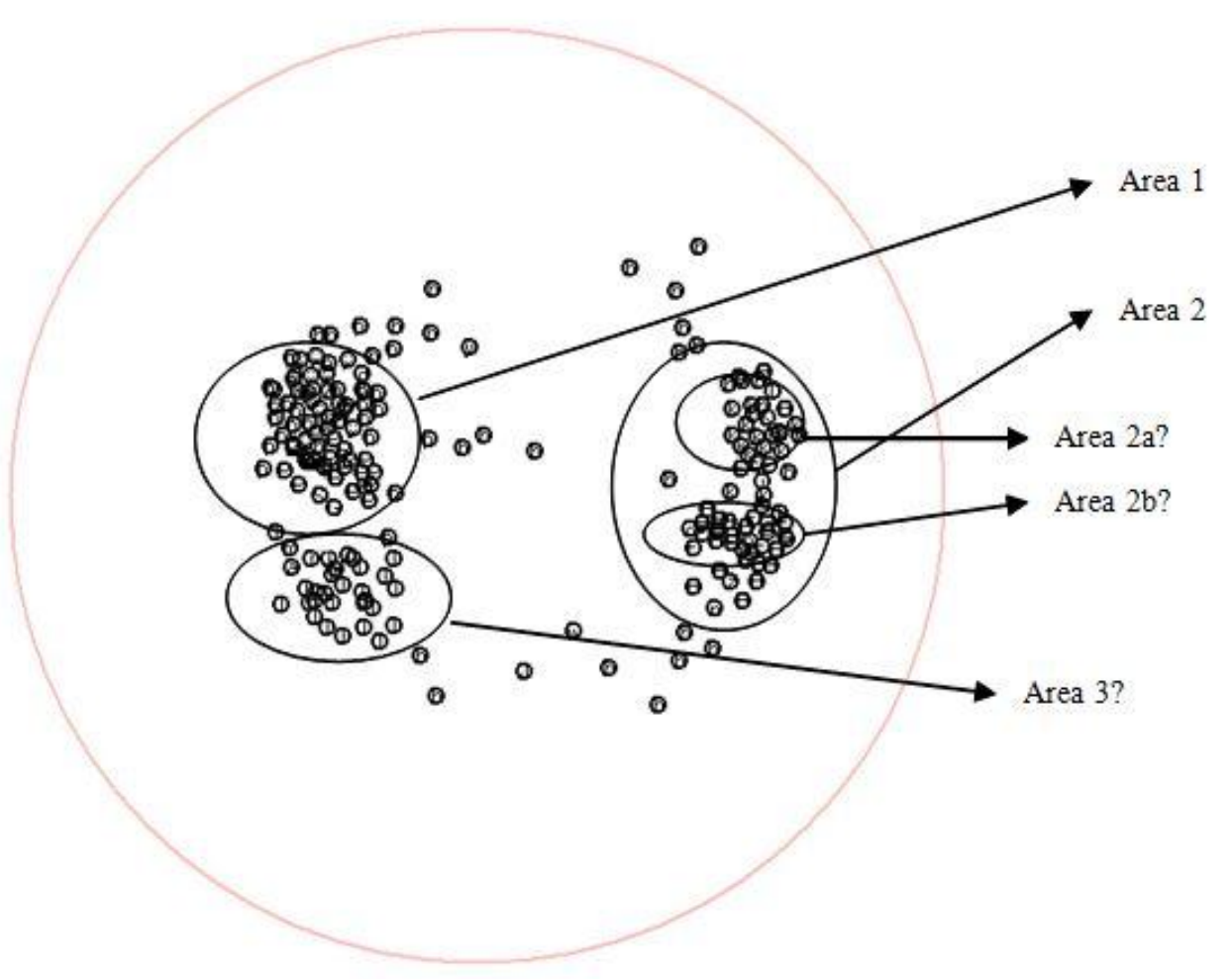

Figure 2: A second-generation semantic map of agent defocusing.

This map gives visual relevance to similarity between contexts. This improves the accuracy of the analysis and captures some facts that would possibly go unnoticed using the classical method. Moreover, such a map provides quantitative evidence that the three situation types identified with the classical method in Sansò (2006) are not equidistant from one another as they appear in the first-generation semantic map in Figure 1. But let us observe it in detail.

Two high-density areas ( 1 and 2 ) emerge clearly on this map. They roughly correspond to the two idealized situation types labeled patient-oriented process and agentless generic event in Sansò (2006). It should be kept in mind, however, that there is nothing "conceptual" in these areas - they only represent clusters of passages that happen to be encoded by the same or very similar morphosyntactic strategies in the languages of the sample. Area 2, corresponding to the

b. Alabó su sabiduría, mencionó su fama, y anunció a los monjes que le había rogado que investigara la muerte de Adelmo (NRS: 139).

'He praised his wisdom, expounded his fame, and informed them that the visitor had been asked to investigate Adelmo's death' (NRE: 96). 
situation type labeled agentless generic event, appears to be less cohesive than Area 1 as a result of the variety of constructions used in the languages of the sample. Possibly, two sub-areas ( $2 \mathrm{a}$ and 2 b) should be identified; although a more systematic analysis is needed in order to decide whether they have any linguistic significance, it can be proposed tentatively that the two subareas may correspond to different degrees of genericity of the agent. Area 2a includes many passages in which the agent corresponds to virtually all humanity (as in (7)), whereas area $2 b$ includes passages in which the generic agent is spatio-temporally bound (i.e. people in a given spatio-temporal setting, as in (8)).

\section{Modern Greek}

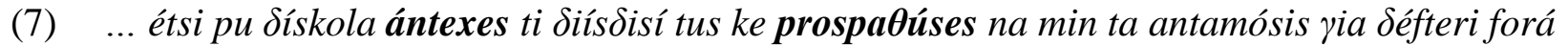
(NRMG: 136-137).

"[In his physiognomy there were what seemed traces of many passions which his will had disciplined but which seemed to have frozen those features they had now ceased to animate. Sadness and severity predominated in the lines of his face, and his eyes were so intense that with one glance they could penetrate the heart of the person speaking to him, and read the secret thoughts,] so it was difficult to tolerate [lit. you could hardly tolerate, AS] their inquiry and one was [lit. you were, AS] not tempted to meet them a second time" (NRE: 73).

(8) ... mas eksíyise óti sto píso méros tu eryastiríu fisúsan to yialí, enó sto brostinó, ópu ítan i

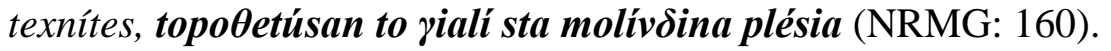

"[Thus we met Nicholas of Morimondo, master glazier of the abbey.] He explained to us that in the rear part of the forge they also blew glass, whereas in this front part, where the smiths worked, the glass was fixed [lit. they fixed glass, AS] to the leads" (NRE: 85).

A less dense area (Area 3 on the map) includes those contexts in which the patient is not topical but the event is realis/past (roughly corresponding to the situation type labeled bare happening). Not surprisingly, this area is less clearly individuated than Areas 1 and 2. Whereas in the classical map in Figure 1 the corresponding situation type was represented as equidistant from the two other situation types, the map in Figure 2 shows that these passages are more similar to passages in which the event is realis/past and the patient is topical. This confirms, by the way, the primacy of agent defocusing over patient promotion as the basic function of passive and impersonal constructions (Shibatani 1985, among many others); two situations are more likely to be encoded by the same constructions if the reasons for defocusing the agent are the same in both cases, irrespective of the topical vs. non-topical status of the patient.

There are also some outliers. Some of them are motivated by idiosyncratic choices made by the translators. In other cases (e.g. in (9)), the position of the circle on the map is motivated by the somewhat hybrid nature of the context in question (a situation in which the patient is highly individuated, but the event is generic): 
(9) “La pergamena non sembrava pergamena... Sembrava stoffa, ma esile..." continuava Bencio. "Charta lintea, o pergamino de pano," disse Guglielmo. "Non ne avevi mai visto?" "Ne ho sentito parlare, ma non credo di averne visto. Si dice sia molto cara, e fragile. Per questo la si usa poco. La fanno gli arabi, vero?" "Sono stati i primi. Ma la fanno anche qui in Italia, a Fabriano" (NRI: 446).

The parchment did not seem like parchment... It seemed like cloth, but very fine..." Benno went on. "Charta lintea, or linen paper," William said. "Had you never seen it?" "I had heard of it, but I don't believe I ever saw it before. It is said to be very costly, and delicate. That's why it is rarely used. The Arabs make it, don't they?" "They were the first. But it is also made here in Italy, at Fabriano" (NRE: 443).

\section{Conceptual Reality Again: High-Density Areas as Situation Types?}

The high-density areas on the map in Figure 2 are relatively complex "entities", determined by a bundle of variables with identical (or similar) values (to recall but a few: the relative topicality of the participants; the specificity of the agent; the temporal/aspectual properties of the event, etc.). If we consider these high-density areas as corresponding to grammatical meanings/functions in the classical sense, second-generation semantic maps appear to be more similar to functional domains in the sense of Givón (1981: 165ff.) than to the bi-dimensional representations of conceptual space envisaged by practitioners of classical semantic maps. Most commonly grammatical meanings/functions are not totally discrete, and the functional space associated with different grams is a continuum in which some dense areas may be singled out only by resorting to linguistic evidence, i.e. identifying the most common grams used to code a given functional domain and comparing the behavior of such grams across languages. Glossing over the aberrant cases, these dense areas can be thought of as situation types in the classical sense, i.e. as conceptually significant configurations defined by clusters of contexts that are systematically associated with identifiable means of expression from language to language. However, there is no principled way to determine whether the use of a given construction in a given language depends on a set of contexts taken in their globality (i.e. as bundles of semantic/pragmatic features) or is simply triggered by a single semantic or pragmatic property of this set of contexts which constitutes a sufficient condition for the use of that construction. After all, it must be kept in mind that voice constructions are not obligatory strategies on a par with, say, the use of a given case or agreement pattern.

Should we then deny any conceptual significance to these constellations of traits? A conclusive answer to this question is impossible. It is a fact that the human ability of conceptualizing real-world configurations from different points of view or at different degrees of granularity is universal. The use of passive constructions when patients are highly individuated lines up with the propensity to conceptualize situations from the point of view of the patient, which is as central to human thought as the concept itself of patient is. The situation type labeled as agentless generic event is basic in that it represents a situation in which an agent, usually human, is understood to exist, but is defocused because of its genericity. The situation type labeled bare happening is also basic to human cognition. It allows the speaker to construe a past event as a purely existential predication (there was x/it happened that $x$ ), without mentioning the agent and without choosing the point of view of the patient. The conceptual reality of these situation types might even turn out to be confirmed by other, independent types of evidence (e.g. 
by psycholinguistic experiments), but the issue of conceptual reality is bound to remain a purely speculative question when building second-generation semantic maps. Perhaps, it is also a relatively uninteresting and marginal problem from the point of view of the creators of such maps.

This conclusion might not appear particularly encouraging to those linguists who wish to make claims about mental representations, but it should be sufficiently clear that representing cross-linguistic variation by means of a second-generation semantic map has no serious disadvantages with respect to first-generation semantic maps; while a traditional map is a theoretical construct which abstracts away from the vagaries of real usage in order to reach plausible representations of how humans conceptualize and categorize situations, a secondgeneration map is a self-sufficient tool which represents exactly the kind of linguistic evidence that the linguist needs in order to do cross-linguistically valid generalizations. Nothing more, but also - crucially — nothing less than this.

\section{Abbreviations}

3 third person; AUX auxiliary; INF infinitive; IPFV imperfective; PL plural; PPTCP past participle; PRS present; PST past; REFL reflexive pronoun; REL relativizer; SG singular.

\section{References}

Croft, William. 2001. Radical Construction Grammar. Syntactic theory in typological perspective. Oxford: Oxford University Press.

Croft, William and Keith T. Poole. 2008. Inferring universals from grammatical variation: Multidimensional scaling for typological analysis. Theoretical Linguistics 34/1.1-37.

Cysouw, Michael. 2007. Building semantic maps: The case of person marking. New challenges in typology: Broadening the horizons and redefining the foundations, ed. by Matti Miestamo and Bernhard Wälchli, 225-247. Berlin: de Gruyter.

Dezső, László. 1988. Passiveness in Hungarian: with reference to Russian passive. Passive and voice, ed. by Masayoshi Shibatani, 291-328. Amsterdam: Benjamins.

Givón, T. 1981. Typology and functional domains. Studies in Language 5.163-193.

----. 1983. Topic continuity in discourse: an introduction. Topic continuity in discourse: A quantitative cross-language study, ed. by Talmy Givón, 1-41. Amsterdam: Benjamins.

----. 1995. Functionalism and grammar. Amsterdam: Benjamins.

Haspelmath, Martin. 1990. The grammaticization of passive morphology. Studies in Language 14/1.25-72.

----- 2003. The geometry of grammatical meaning: Semantic maps and cross-linguistic comparison. The new psychology of language, vol. 2: Cognitive and functional approaches to language structure, ed. by Michael Tomasello, 211-242. Mahwah, NJ: Erlbaum.

Kemmer, Suzanne. 1993. The middle voice. Amsterdam: Benjamins.

----. 2003. Human cognition and the elaboration of events. The new psychology of language, vol. 2: Cognitive and functional approaches to language structure, ed. by Michael Tomasello, 89-118. Mahwah, NJ: Erlbaum.

Langacker, Ronald W. 2006. Dimensions of defocusing. Voice and grammatical relations. In honor of Masayoshi Shibatani, ed. by Tasaku Tsunoda and Taro Kageyama, 115-137. Amsterdam: Benjamins. 
Levinson, Stephen and Sergio Meira. 2003. 'Natural concepts' in the spatial topological domain - Adpositional meanings in crosslinguistic perspective: An exercise in semantic typology. Language 79/3.485-516.

Myhill, John. 1997. Towards a functional typology of agent defocusing. Linguistics 35.799-844. Sansò, Andrea. 2006. 'Agent defocusing' revisited: Passive and impersonal constructions in some European languages. Passivization and typology: Form and function, ed. by Werner Abraham and Larisa Leisiö, 239-270. Amsterdam: Benjamins.

Shibatani, Masayoshi. 1985. Passives and related constructions: a prototype analysis. Language 61.821-848.

-----. 2006. On the conceptual framework for voice phenomena. Linguistics 44/2.217-269.

van der Auwera, Johan. 2008. In defense of classical semantic maps. Theoretical Linguistics 34/1.39-46.

Wälchli, Bernhard. 2006/7. Constructing semantic maps from parallel text data. Manuscript.

\section{Sources}

NRD = Eco, Umberto. 2003. Rosens navn. Danish translation by Poul Lange. København: Forum.

$\mathrm{NRE}=$ Eco, Umberto. 1998. The name of the rose. English translation by William Weaver. London: Vintage.

$\mathrm{NRF}=$ Eco, Umberto. 1982. Le Nom de la rose. French translation by Jean-Noël Schifano. Paris: Grasset \& Fasquelle.

$\mathrm{NRH}=$ Eco, Umberto. 2007. A rozsa neve. Hungarian translation by Imre Barna. Budapest: Európa Kőnyvkiadó.

NRI = Eco, Umberto. 1980. Il nome della rosa. Milano: Fabbri-Bompiani-Sonzogno.

NRMG = Eco, Umberto. 2000. To ónoma tou ródou. Greek translation by Éfi Kallifatídi. Athens: Ellénika Grámmata.

NRP = Eco, Umberto. 2001. Imię róży. Polish translation by Adam Szymanowski. Warszawa, Porozumienie Wydawców.

NRS = Eco, Umberto. 2000. El nombre de la rosa. Spanish translation by Ricardo Pochtar. Barcelona: Plaza \& Janés.

Author's contact information:

Andrea Sansò

Scienze della Mediazione Interlinguistica e Interculturale Facoltà di Giurisprudenza

Università dell’Insubria Via S. Abbondio 9 I-22100

Como, Italy

asanso@gmail.com 


\section{Appendix - Selected Passages from the Corpus Il Nome della Rosa}

(10) “Llevas un nombre grande y muy bello” dijo “ ¿Sabes quién fue Adso de Montier-enDer?" preguntó. Confieso que no lo sabía. Y el mismo Jorge respondió: "Fue el autor de un libro grande y tremendo, el Libellus de Antichristo, donde profetizó lo que habría de suceder... pero no lo escucharon como merecía." "El libro fue escrito antes del milenio" dijo Guillermo "y esos hechos no se produjeron”... (NRS: 122).

"You bear a great and very beautiful name," he said. "Do you know who Adso of Montier-en-Der was?" he asked. I did not know, I confess. So Jorge added, "He was the author of a great and awful book, the Libellus de Antichristo, in which he foresaw things that were to happen; but he was not sufficiently heeded." "The book was written before the millennium," William said, "and those things did not come to pass..." (NRE: 83).

(11) Venancio, que conoce ... que conocía muy bien el griego, dijo que Aristóteles había dedicado especialmente a la risa el segundo libro de la Poética y que si un filósofo tan grande había consagrado todo un libro a la risa, la risa debía de ser algo muy importante. Jorge dijo que muchos padres habían dedicado libros enteros al pecado, que es algo importante pero muy malo, y Venancio replicó que por lo que sabía Aristóteles había dicho que la risa era algo bueno, y adecuado para la transmisión de la verdad, y entonces Jorge le preguntó desafiante si acaso había leído ese libro de Aristóteles, y Venancio dijo que nadie podía haberlo leído todavía porque nunca se había encontrado y quizá estaba perdido. $Y$, en efecto, nadie ha podido leer el segundo libro de la Poética. Guillermo de Moerbeke nunca lo tuvo entre sus manos. Entonces Jorge dijo que si no lo habían encontrado era porque nunca se había escrito, porque la providencia no quería que se glorificaran cosas frívolas (NRS: 160). Venantius, who knows ... who knew Greek very well, said that Aristotle had dedicated the second book of the Poetics specifically to laughter, and that if a philosopher of such greatness had devoted a whole book to laughter, then laughter must be important. Jorge said that many fathers had devoted entire books to sin, which is an important thing, but evil; and Venantius said that as far as he knew, Aristotle had spoken of laughter as something good and an instrument of truth; and then Jorge asked him contemptuously whether by any chance he had read this book of Aristotle; and Venantius said that no one could have read it, because it has never been found and is perhaps lost forever. And, in fact, William of Moerbeke never had it in his hands. Then Jorge said that if it had not been found, this was because it had never been written, because Providence did not want futile things glorified (NRE: 112).

(12) Y Adelmo citó en aquella ocasión a otra autoridad eminentísima, la del doctor de Aquino, cuando dijo que conviene que las cosas divinas se representen más en la figura de los cuerpos viles que en la figura de los cuerpos nobles (NRS: 120).

And Adelmo that day quoted another lofty authority, the doctor of Aquino, when he said that divine things should be expounded more properly in figures of vile bodies than of noble bodies (NRE: 81). 
Polish

(13) Jest jednakowoż okres poprzedzajacy przybycie Mikołaja, kiedy bibliotekarzem jest Pawet z Rimini. Od kiedy nim byt? Tego nam nie wyjawiono, moglibyśmy przejrzeć rejestry opactwa, ale mniemam, że sq u opata, a w tym momencie wolatbym go o tę rzecz nie prosić. Postawmy hipoteze, że Pawel byt wybrany na bibliotekarza sześćdziesiąt lat temu, pisz. Czemu Alinard boleje nad tym, że około pięćdziesięciu lat temu jemu powinno przypaść stanowisko bibliotekarza, a zostało oddane innemu? Czy miat na myśli Pawła z Rimini? (NRP: 607).

There is a period, however, before Nicholas came, when Paul of Rimini was librarian. How long was he in that post? We weren't told. We could examine the abbey ledgers, but I imagine the abbot has them, and for the moment I would prefer not to ask him for them. Let's suppose Paul was appointed librarian sixty years ago. Write that. Why does Alinardo complain of the fact that, about fifty years ago, he should have been given the post of librarian and instead it went to another? Was he referring to Paul of Rimini? (NRE: 440).

(14) I czemu ograniczać podejrzenia do tych tylko, którzy uczestniczyli w rozmowie o śmiechu? Może motywy zbrodni byly inne, może nie miaty nic wspólnego z biblioteka. Tak czy inaczej dwie rzeczy sq niezbędne: musimy wiedzieć, jak wchodzi się do biblioteki noca, i mieć światto. O to zadbaj ty. Pokręcisz się po kuchni w porze obiadu, weźmiesz kaganek...(NRP: 193).

And why limit our suspicions only to those who took part in the discussion of laughter? Perhaps the crime had other motives, which have nothing to do with the library. In any case, we need two things: to know how to get into [lit. how one gets into, $A S]$ the library at night, and a lamp. You provide the lamp. Linger in the kitchen at dinner hour, take one... (NRE: 140).

\section{Danish}

„Det har jeg også hørt tale om, men det er en meget gammel historie, noget som skete for mindst halvtreds år siden. Da jeg kom hertil, var Roberto fra Bobbio bibliotekar, og de gamle ymtede noget om, at der var blevet begået en uretfardighed mod Alinardo. Jeg vil ikke gå i dybden med sagen, fordi det forekommer mig at vare et brud på respekten for de aldre, og jeg vil ikke lytte til sladder. Roberto havde en medhjalper, som senere dфde, og i hans sted blev Malachia udnavnt, da han endnu var meget ung. Mange mente, at han ikke var kvalificeret, at han påstod at kunne grask og arabisk, men at det ikke var sandt, at han kun var god til at abe efter, og kopierede manuskripter på disse sprog med en smuk kalligrafi, uden at forstå hvad det var, han skrev af." (NRD: 401).

"I, too, have heard talk of that, but it is an old story, dating back at least fifty years. When I arrived here the librarian was Robert of Bobbio, and the old monks muttered about an injustice committed against Alinardo. Robert had an assistant, who later died, and Malachi, still very young, was appointed in his place. Many said that Malachi was without merit, that though he claimed to know Greek and Arabic it was not true, 
he was only good at aping, copying manuscripts in those languages in fine calligraphy, without understanding what he was copying." (NRE: 420).

Hvor mange klostre var ikke for to hundrede år siden lysende midtpunkter for storhed og hellighed, mens de nu er tilholdssteder for dovenkroppe. Ordenen er stadig magtfuld, men stanken fra byerne strammer sig sammen omkring vore hellige steder, Guds folk er nu henfalden til handel og partistridigheder. Dernede i de store befolkede områder, hvor helligheden ikke laengere sidder i højsadet, ikke bare taler man ... men man skriver også på folkesproget. (NRD: 36).

How many of our abbeys, which two hundred years ago were resplendent with grandeur and sanctity, are now the refuge of the slothful? The order is still powerful, but the stink of the cities is encroaching upon our holy places, the people of God are now inclined to commerce and wars of faction; down below in the great settlements, where the spirit of sanctity can find no lodging, not only do they speak ... in the vulgar tongue, but they are already writing in it. (NRE: 36).

(17) Han erklaerede nemlig den romerske kirke for en skøge, og sagde ... at en indviet kirke ikke er noget vard for bønnen, ikke mere end en stald, og at Kristus kan tilbedes $\boldsymbol{i}$ skove såvel som i kirker. (NRD: 220).

He declared the Roman church a whore, [and] said that ... a consecrated church was worthless for prayer, no better than a stable, and Christ could be worshiped both in the woods and in the churches. (NRE: 228-229).

\section{Modern Greek}

(18) "kalúse tus pistús tu na yínun ómii me tus apostólus, ke îele na dósi sti fatría tu to ónoma táyma ton apostólon, ke i dikí tu na yirízun ton kósmo san ftoxí epétes, zóntas

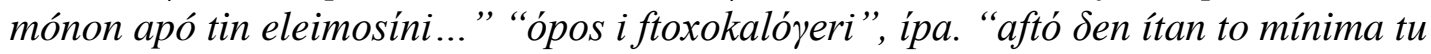

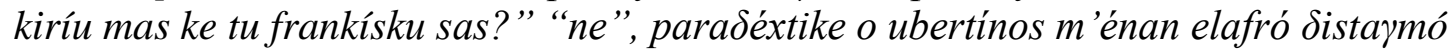

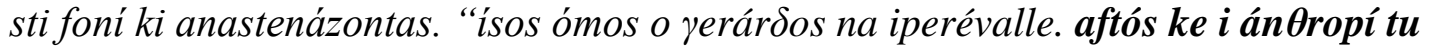

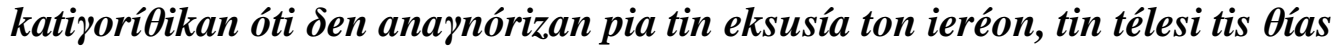
lituryías ke tin eksomológisi, ki óti ítan aryósxoli planítes". (NRMG: 397).

"He enjoined his disciples to imitate the apostles, and he chose to call his sect the order of the Apostles, and his men were to go through the world like poor beggars, living only on alms...." "Like the Fraticelli," I said. "Wasn't this the command of our Lord and of your own Francis?" "Yes," Ubertino admitted with a slight hesitation in his voice, sighing. "But perhaps Gherardo exaggerated. He and his followers were accused of denying the authority of the priests and the celebration of Mass and confession, and of being idle vagabonds." (NRE: 222).

o kerós xirotéreve. íxe sikoӨi énas kríos aéras ke o uranós skepazótan me omíxli. mánteves ton ílio na díi piso ap’ ta perivólia, ke skotádi aplonótan stin anatolí, ópu katefӨinómastan pernóntas dípla apó to xorostásio tis ekklisías ke ftánontas sto píso tmíma tu oropedíu (NRMG: 158).

The weather was turning bad. A cold wind had risen and the sky was becoming foggy. The sun could be sensed [lit. you could sense the sun, $A S$ ], setting beyond the vegetable gardens, and toward the east it was already growing dark as we proceeded 
in that direction, flanking the choir of the church and reaching the rear part of the grounds (NRE: 84-85).

(20) “lío polí. i piratés tu makrinú vorrá éftanan apó ta potámia kai leilatúsan ti rómi. $i$

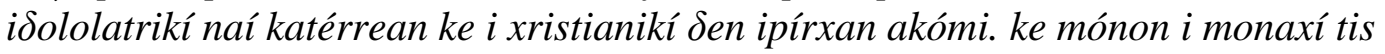

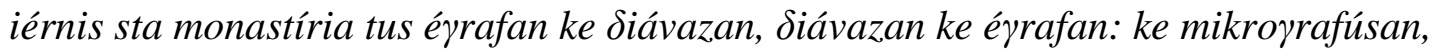

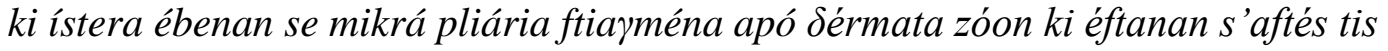
perioxés yia na kiríksun to evanyélio san na ísastan ápisti, katálaves? píjes sto bóbio,

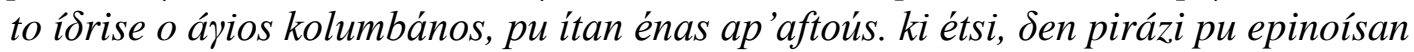

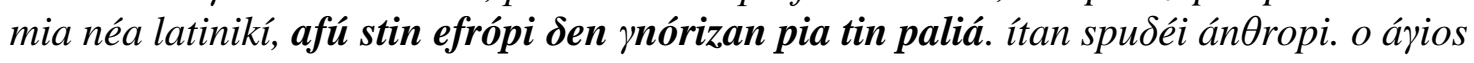
vrandános éftase os ta nisiá tis kalís tíxis ke paréplefse tis aktés tis kólasis, ópu íde ton iúda alisodeméno s'énan vráxo, ke mia méra árakse ke katévike s'éna nisí, to opío ítan éna Aalássio téras. itan trelí, fisiká”, epanélave me ikanopoíisi (NRMG: 559-560).

"More or less. Vikings from the Far North came down along the rivers to sack Rome. The pagan temples were falling in ruins, and the Christian ones did not yet exist. It was only the monks of Hibernia in their monasteries who wrote and read, read and wrote, and illuminated, and then jumped into little boats made of animal hide and navigated toward these lands and evangelized them as if you people were infidels, you understand? You have been to Bobbio, which was founded by Saint Columba, one of them. And so never mind if they invented a new Latin, seeing that in Europe no one knew the old Latin any more. They were great men. Saint Brendan reached the Isles of the Blest and sailed along the coasts of hell, where he saw Judas chained to a rock, and one day he landed on an island and went ashore there and found a sea monster. Naturally they were all mad," he repeated contentedly (NRE: 312-313).

\section{Spanish}

“A todo esto, llegó el invierno, el invierno de 1305, uno de los más rigurosos de aquellas décadas, y la miseria se instaló en las comarcas circundantes. Dulcino envió una tercera carta a sus seguidores, y otros muchos se unieron a su gente. Pero alli arriba la vida se había vuelto imposible y el hambre llegó a ser tal que comieron la carne de los caballos y otros animales, y heno cocido. Y muchos murieron." "Pero, ¿contra quién peleaban en aquel momento?" "El obispo de Vercelli había apelado a Clemente $V$ y éste había convocado una cruzada contra los herejes. Se decretó la indulgencia plenaria para todos aquellos que participaran en la misma, y se pidió ayuda a Ludovico de Saboya, a los inquisidores de Lombardia y al arzobispo de Milán. Fueron muchos los que cogieron la cruz para auxiliar a las gentes de Vercelli y de Novara, desplazándose incluso desde Saboya, desde Provenza y desde Francia, y todos se pusieron bajo las órdenes del obispo de Vercelli. Los choques entre las vanguardias de ambos ejércitos se sucedían con mucha frecuencia, pero las fortificaciones de Dulcino eran inexpugnables, y los impíos se las arreglaban para recibir refuerzos " (NRS: 328329).

"Meanwhile winter had come, the winter of the year 1305, one of the harshest in recent decades, and there was great famine all around. Dolcino sent a third letter to his followers, and many more joined him, but on that hill life had become intolerable, and 
they grew so hungry that they ate the flesh of horses and other animals, and boiled hay. And many died" "But whom were they fighting against now?" "The Bishop of Vercelli had appealed to Clement the Fifth, and a crusade had been called against the heretics. A plenary indulgence was granted to anyone taking part in it, and Louis of Savoy, the inquisitors of Lombardy, the Archbishop of Milan were prompt to act [lit. were asked for help, $A S$ ]. Many took up the cross to aid the people of Vercelli and Novara, even from Savoy, Provence, France; and the Bishop of Vercelli was the supreme commander. There were constant clashes between the vanguards of the two armies, but Dolcino's fortifications were impregnable, and somehow the wicked received help." (NRE: 229).

Polish

(22) Przez chwile nie wiedziałem, o co mu chodzi. Potem przypomniałem sobie. Prawda! Wyleciat mi z głowy tytut, ale któryż dorosły mnich i któryż rozbrykany mniszek nie uśmiechat się lub nie śmiał z rozmaitych obrazów, proza i rymowanych, tej historii, należacej do tradycji rytuatu wielkanocnego i ioca monachorum? Choć jest zabroniona lub potępiana przez surowszych spośród mistrzów nowicjuszy, nie ma jednak klasztoru, w którym mnisi nie szeptaliby jej sobie na ucho, rozmaicie ujętej $i$ uporządkowanej, i niejedni pobożnie przepisywali ja, twierdzac, że pod ucieszna maska skrywa tajemne nauki moralne; inni zaś zachęcali do jej rozpowszechniania, gdyż-powiadali-poprzez zabawę młodzież może łatwiej nauczyć się na pamięć epizodów świętej historii. Wersję wierszem napisano dla papieża Jana VIII z dedykacja: "Ludere me libuit, ludentem, papa Johannes, accipe. Ridere, si placet, ipse potes." I opowiadano, że sam Karol Łysy wystawit ja na scenie w ksztatcie uciesznego świętego misterium, $w$ wersji rymowanej, by zabawić przy wieczerzy swych dostojników (NRP: 603-604).

I remained puzzled briefly. Then I remembered. He was right! Perhaps I had forgotten the title, but what adult monk or unruly young novice has not smiled or laughed over the various visions, in prose or rhyme, of this story, which belongs to the tradition of the paschal season and the ioca monachorum? Though the work is banned or execrated by the more austere among novice masters, there is still not a convent in which the monks have not whispered it to one another, variously condensed and revised, while some piously copied it, declaring that behind a veil of mirth it concealed secret moral lessons, and others encouraged its circulation because, they said, through its jesting, the young could more easily commit to memory certain episodes of sacred history. A verse version had been written for Pope John VIII, with the inscription "I loved to jest; accept me, dear Pope John, in my jesting. And, if you wish, you can also laugh." And it was said that Charles the Bald himself had staged it, in the guise of a comic sacred mystery, in a rhymed version to entertain his dignitaries at supper (NRE: 437).

\section{Danish}

„Hvem var den mand, I talte om?" spurgte William. Han stirrede forbavset på os. „Hvem jeg talte om? Det husker jeg ikke... det var så laenge siden. Men Gud straffer, 
Gud udsletter, Gud fordunkler selv minderne. Der blev begået mange hovmodige handlinger i biblioteket. Iscer efter det faldt i fremmedes hoender ... Gud straffer stadig... "Vi kunne ikke få mere ud af ham, og vi overlod ham til sit tavse og forbitrede delirium. William lod til at vare højst interesseret i samtalen: „, Alinardo er en mand, man bor lytte til, hver gang han åbner munden, siger han noget interessant. " (NRD: 292-293).

"Who was the monk you were speaking of?" William asked. He looked at us, stunned. "Whom was I speaking of? I cannot remember ... it was such a long time ago. But God punishes, God nullifies, God dims even memories. Many acts of pride were committed in the library. Especially after it fell into the hands of foreigners. God punishes still...." We could get no more out of him, and we left him to his calm, embittered delirium. William declared himself very interested in that exchange: "Alinardo is a man to listen to; each time he speaks he says something interesting." (NRE: 303-304). 